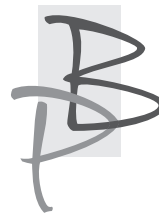

Dorota Krystyna Rembiszewska*

Instytut Slawistyki Polskiej Akademii Nauk, Warszawa

https://orcid.org/0000-0003-0339-0879

\title{
Interdyscyplinarne spotkania naukowe z cyklu "Kolokwia Wschodnie". Sprawozdanie
}

W czasach wszechogarniającej punktozy, pogoni naukowców za wypełnianiem slotów publikacyjnych i konieczności sprostania wymogom nielogicznej parametryzacji, jakiekolwiek inicjatywy humanistycznych środowisk naukowych, niemieszczące się w ramach urzędniczych wytycznych, wydają się bez sensu. Na przekór temu, co się wokół dzieje, powstał zamysł zorganizowania spotkań naukowych skupionych wokół zagadnień, pojemnego znaczeniowo, Wschodu.

Kolokwia wschodnie - interdyscyplinarne spotkania naukowe zrodziły się z potrzeby wymiany myśli, doświadczeń, wzajemnych inspiracji przedstawicieli ośrodków naukowych reprezentujących dyscypliny humanistyczne. Inicjatorami tych spotkań byli dr hab. Dorota K. Rembiszewska, prof. IS PAN z Instytutu Slawistyki Polskiej Akademii Nauk w Warszawie i prof. dr hab. Jarosław Ławski, dziekan Wydziału Filologicznego Uniwersytetu w Białymstoku.

* Dorota Krystyna Rembiszewka - dr hab., prof. w Instytucie Slawistyki Polskiej Akademii Nauk; autorka licznych książek, m.in. „Stownik dialektu knyszyńskiego” Czesława Kudzinowskiego (Łomża 2007), współautorka Atlasu gwar wschodniostowiańskich Białostocczyzny (t. IV, IX, X) oraz (z Ireną Maryniakową, Januszem Siatkowskim) Różnojęzycznego słownictwa gwarowego Podlasia, Suwalszczyzny i pótnocno-wschodniego Mazowsza (Warszawa 2014). 


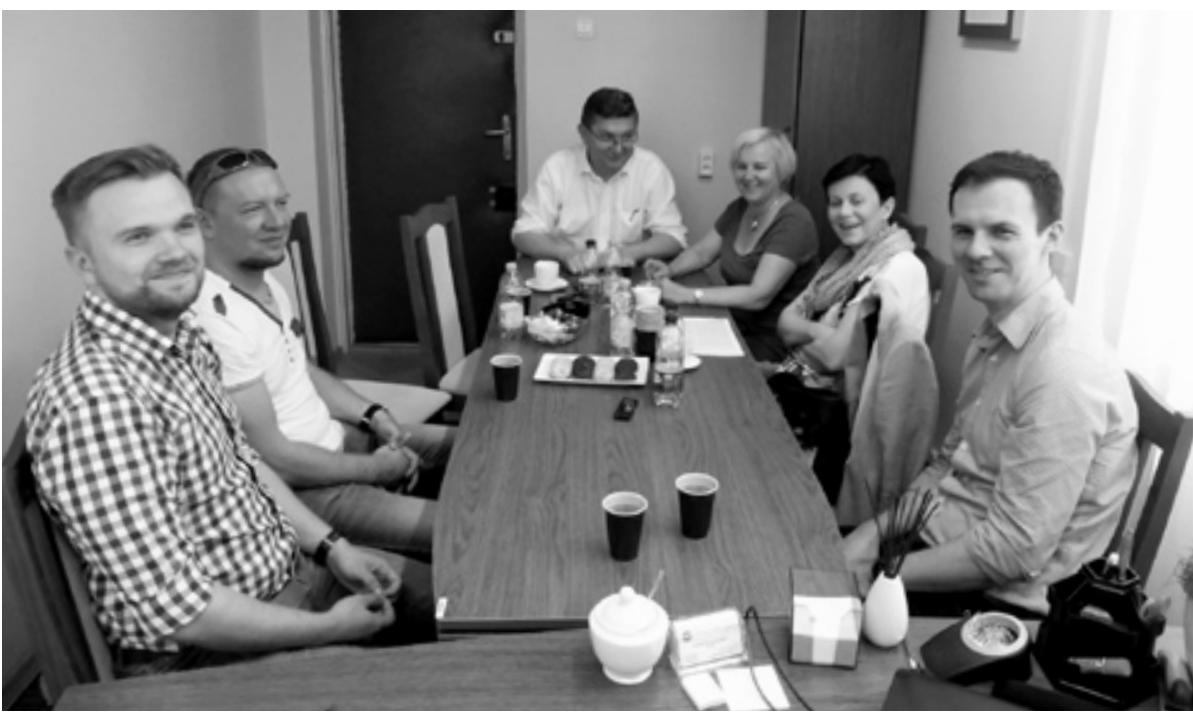

Od lewej: dr Łukasz Zabielski, dr Marcin Bajko, prof. Jarosław Ławski, dr hab. Dorota K. Rembiszewska, dr hab. Anna Janicka, dr Konrad Szamryk. Spotkanie nr 1: Białystok 27 VI 2018 r.

Pierwsze Kolokwia zorganizowała w Białymstoku Katedra Badań Filologicznych „Wschód - Zachód” Wydziału Filologicznego Uniwersytetu w Białymstoku, 27 czerwea 2018 roku.

$\mathrm{Na}$ pierwszym spotkaniu podjęto temat interesujący zarówno literaturoznawców, jak i lingwistów. Dyskutowano bowiem o biografiach, tekstach wspomnieniowych językoznawców z kręgu warszawskiej slawistyki. Uczestnicy Kolokwiów, po wcześniejszej lekturze książek: Ewy Rzetelskiej-Feleszko Życie we wspomnieniach, Irydy Grek-Pabisowej W kręgu mojego życia (ludzie, zdarzenia, czasy), Ireny Maryniakowej Stodkie mleko, gorzkie wspomnienia, Zdzisław Stieber (1903-1980). Materiały i wspomnienia, zastanawiali się nad granicami otwartości, ujawniania intymnych wątków z życia w biografiach i autobiografiach. Rozpatrywano także kwestię przydatności autobiografii w tworzeniu monografii biograficznych. Wybrane według określonego kryterium publikacje wskazują, że tego typu teksty są nie tylko interesującym materiałem do badań nad historią danej dziedziny wiedzy, ale też pokazują różne stopnie intensywności subiektywizmu opisywanych i komentowanych zdarzeń. Konstruowanie i rekonstruowanie tych samych faktów pojawiających 
się w omawianych tekstach dobitnie świadczy o dużej dowolności w interpretowaniu rzeczywistości. Zestawienie wspomnień osób z tego samego środowiska, gdzie w sposób oczywisty pojawiają się te same wątki i osoby, unaocznia wielość różnorodnych ocen, rzadko kiedy obiektywnych.

Kolejne Kolokwia wschodnie - 2 grudnia 2018 r. - gościł Instytut Slawistyki PAN w siedzibie Zbiorów Specjalnych IS PAN. Osią dyskusji było wystąpienie dra hab. Kazimierza Sikory, prof. UJ z Katedry Historii Języka i Dialektologii Uniwersytetu Jagiellońskiego pt. Dyskurs stadionowej nienawiści na przykładzie Krakowa. Było ono (i towarzysząca mu multimedialna prezentacja) poświęcone mowie nienawiści, obecnej coraz silniej we współczesnym dyskursie sportowym, głównie za sprawą fanatycznych kibiców piłkarskich (tzw. szalikowców, hoolsów, kiboli).

Prof. Sikora stwierdził, że wśród miast Polski, gdzie stadionowe chuligaństwo przybrało szczególnie drastyczne formy (liczne zabójstwa, okaleczenia, gangsterskie porachunki bojówek obu klubów), niechlubny prym wiedzie Kraków i jego „święta wojna” pseudokibiców dwóch najstarszych polskich

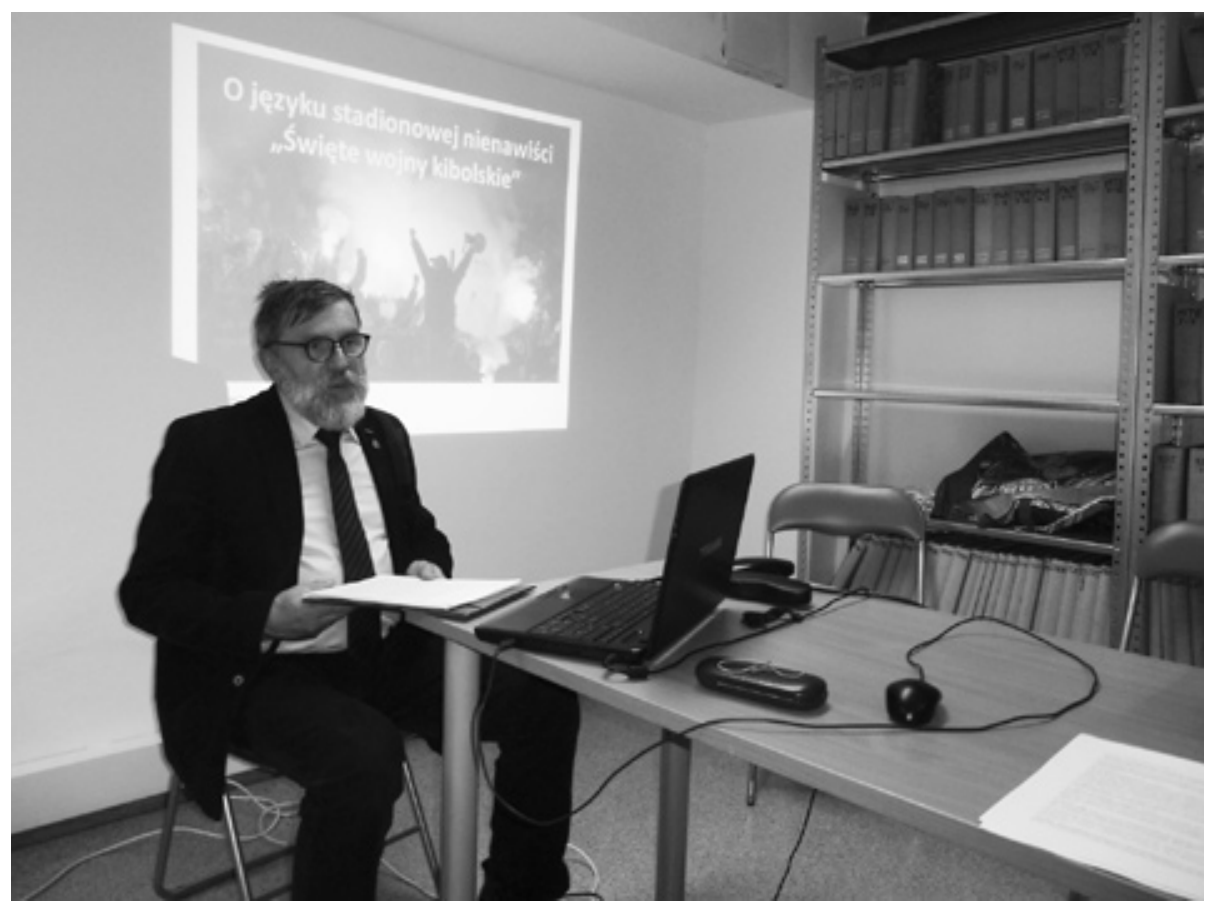

Dr hab. Kazimierz Sikora, prof. UJ. Spotkanie nr 2: Warszawa 2 XII 2018 r. 
klubów: Cracovii i Wisły Kraków. Niechęć, zadawnione urazy, krzywdy, które towarzyszyły od wielu dziesiątków lat rywalizacji sportowej, a po powrocie Cracovii (po 20 latach) w 2004 roku do ekstraklasy, przybrały postać jawnej wrogości i nienawiści, bezwzględnego konfliktu, wręcz „plemiennej” waśni, która stawia sobie za cel panowanie nad miastem, zupełnie zniszczenie i upodlenie przeciwnika. Konflikt ten rozprzestrzenił się - jest widoczny w przestrzeni miejskiej (graffiti, murale, wlepki) Krakowa i wielu miast południowej Małopolski oraz w Internecie. Także język tej „,wojny”, dążący do poniżenia, wyszydzenia, deprecjacji, dehumanizacji przeciwnika, odznacza się wyjątkową brutalnością i wulgarnością, dominują w nim obelgi i wyzwiska, insynuacje, rozmaite, negatywnie wartościujące, rzeczowniki (np. $\dot{y} y d$, pies, pedat, ubek itd.). Są to jawnie konfrontacyjne, niepozostawiające żadnej przestrzeni na refleksję, dialog i żart, środki werbalnej agresji, prowadzące jedynie do eskalacji przemocy na osiedlach i ulicach miasta. Dlatego też autor wystąpienia uznał to groźne społecznie zjawisko za szczególną postać mowy niena-

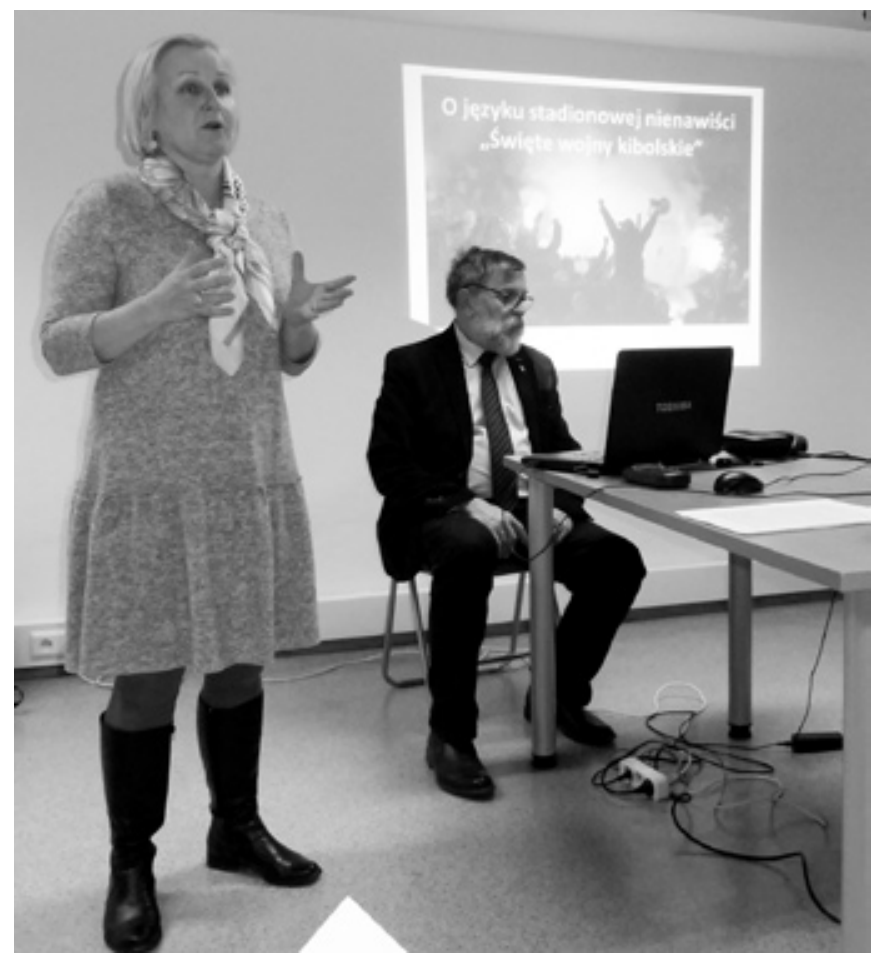

Od lewej: dr hab. Dorota K. Rembiszewska, dr hab. Kazimierz Sikora. Spotkanie nr 2: Warszawa 2 XII $2018 \mathrm{r}$. 


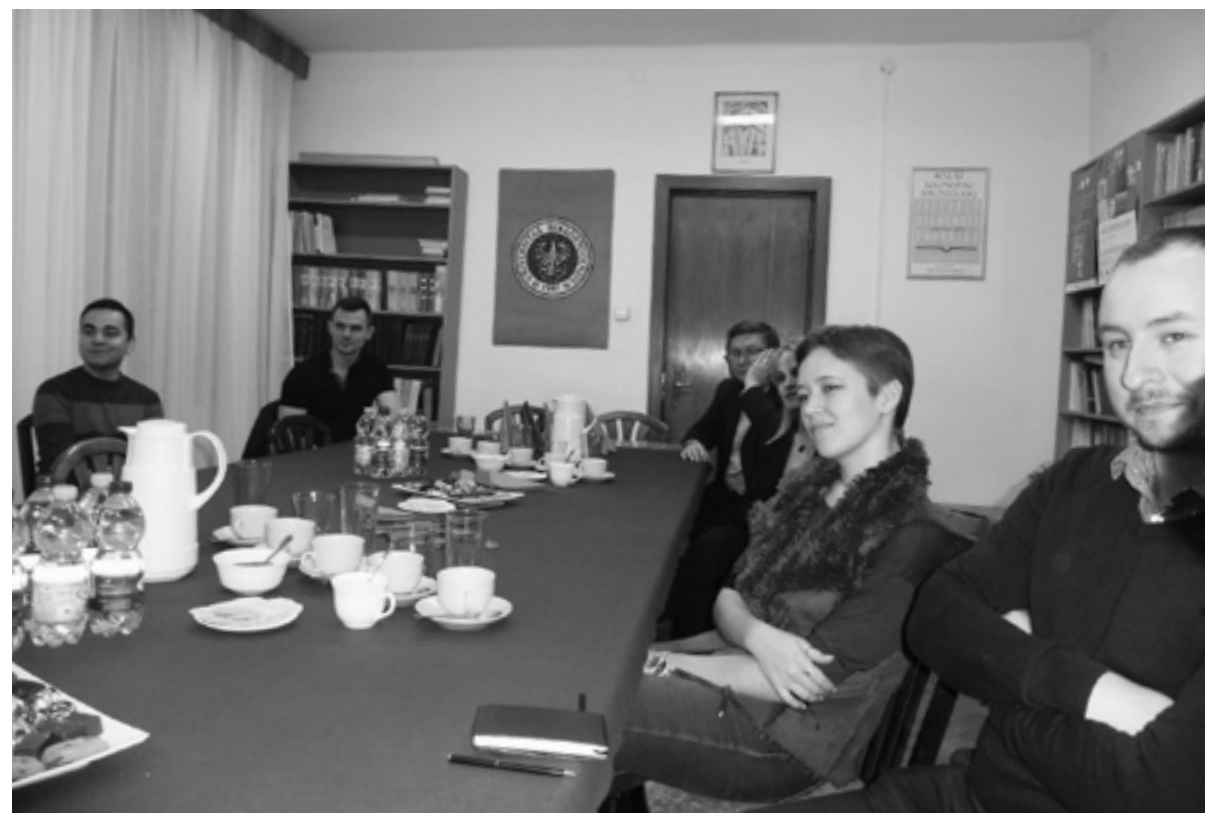

Na zdjęciu uczestnicy spotkania 6 lutego 2019 roku.

Spotkanie nr 2: Białystok. Od lewej: dr Michał Mordań, dr Paweł Dziedziul, prof. Jarosław Ławski, nn, mgr Irena Szewczenko, dr Kamil K. Pilichiewicz

wiści, obracającej się przeciwko kibicom, działaczom, piłkarzom, sympatykom (nawet tym nieżyjącym - przypadki profanacji grobów) przeciwnika.

Referent zwrócił też uwagę, podając przykłady innych miast, na rosnący problem chuligaństwa stadionowego w Polsce.

W dyskusji, moderowanej przez Dorotę K. Rembiszewską z IS PAN, z udziałem doktorantów i pracowników naukowych Uniwersytetu w Białymstoku, Uniwersytetu Jagiellońskiego, skupiono się głównie na przejawach agresji językowej, obecnej na stadionach sportowych, a także na ulicach miast wobec obcokrajowców. Konkluzja dyskusji niestety nie napawała optymizmem. Mowa nienawiści staje się coraz bardziej akceptowana w niektórych środowiskach i wykorzystywana do manipulacji, rozgrywek politycznych.

Znakomitym podsumowaniem części panelowej był spektakl Kibice w reżyserii Michała Buszewicza, wystawiany przez Teatr Żydowski w Teatrze Studio Scena Malarnia. Przedstawienie zasadzało się na niecodziennym pomyśle. Bowiem na deskach teatru spotkali się ci, którzy w rzeczywistości raczej się 


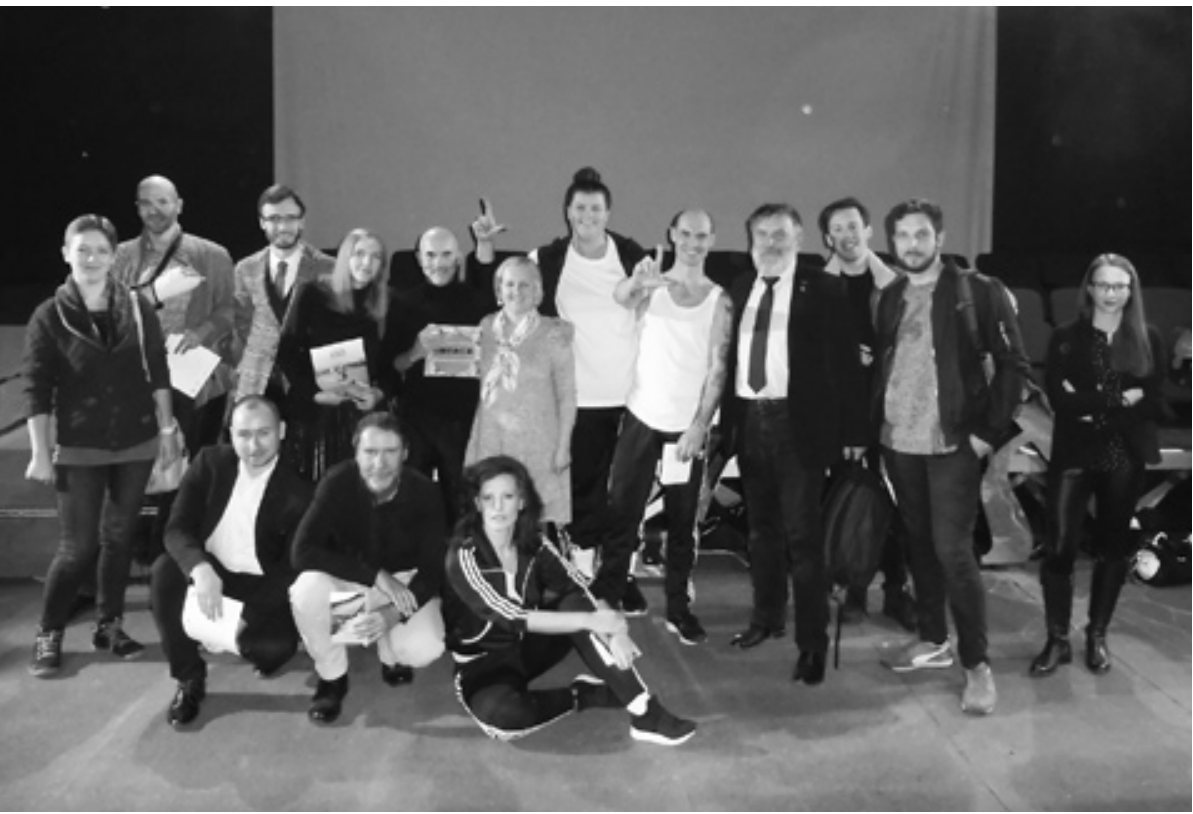

Uczestnicy seminarium, prelegent oraz aktorzy i reżyser spektaklu Kibice

(Teatr Studio Scena Malarnia)

nie spotykają: polscy Żydzi i kibice Legii Warszawa. Jak zaznaczono w programie „Kibice występujący w spektaklu nie są reprezentantami oficjalnych stowarzyszeń kibicowskich ani klubu Legia Warszawa”.

Po przedstawieniu osoby biorące udział w panelu spotkały się z aktorami, reżyserem i autorem scenariusza.

Następne Kolokwia odbyły się 6 lutego 2019 roku. w Katedrze Badań Filologicznych „Wschód - Zachód” Wydziału Filologicznego Uniwersytetu w Białymstoku. Językoznawcy z Warszawy - Dorota K. Rembiszewska i Janusz Siatkowski zaprezentowali swoją książkę Pogranicze polsko-wschodniostowiańskie. Studia wyrazowe (Wydział Polonistyki UW, Warszawa 2018).

Referenci wyjaśnili, że zainteresowanie problematyką pogranicza i tym obszarem wynika z prac nad Ogólnosłowiańskim atlasem językowym (OLA) i rozpatrywaniem wewnątrzsłowiańskich kontaktów językowych. W książce, na przykładzie kilkunastu wyrazów, m.in. chabor 'łapówka', drahle, drygle 'galareta z mięsa', hreczka 'gryka', racuchy 'placki z ciasta drożdżowego lub z tartych kartofli', włóczebne - 'kolędowanie wielkanocne', wołokita 'czło- 
wiek bez zajęcia, włóczęga', ukazali złożoność problematyki kontaktów językowych na wymienionym pograniczu. Autorzy zwrócili także uwagę na trudności metodologiczne przy rozstrzyganiu, czy mamy do czynienia z pożyczką, czy z nawiązaniem między wschodnią i zachodnią Słowiańszczyzną. Z tym wiąże się konieczność prześledzenia funkcjonowania danego wyrazu w konkretnym otoczeniu językowym.

Dorota Rembiszewska i Janusz Siatkowski w swoim wystąpieniu zaznaczyli, że w OLA te pogranicza językowe nie były uwzględnione w sposób wystarczający, zarówno ze względu na zbyt rzadką siatkę punktów, jak i zignorowanie występujących tu punktów dwujęzycznych. Dotyczy to także wschodniego pogranicza Polski z gwarami białoruskimi i ukraińskimi. W OLA zupełnie pominięto obszerną wschodniosłowiańską wyspę językową na Białostocczyźnie, nie uwzględniono też dawniej licznych punktów dwujęzycznych na Lubelszczyźnie. Pogranicze to było przedmiotem już wielu opracowań, które pozwalały na skorygowanie zbyt jednostronnego obrazu wymienionych terenów w OLA, ale ostatnio nagromadzono wielkie bogactwo materiałów $\mathrm{z}$ tego pogranicza, które nasunęło potrzebę ponownego rozpatrzenia polskoruskich kontaktów językowych. Nowe materiały pozwoliły na uzupełnienie i skorygowanie wielu dawniejszych ustaleń, na uściślenie zasięgów pożyczek

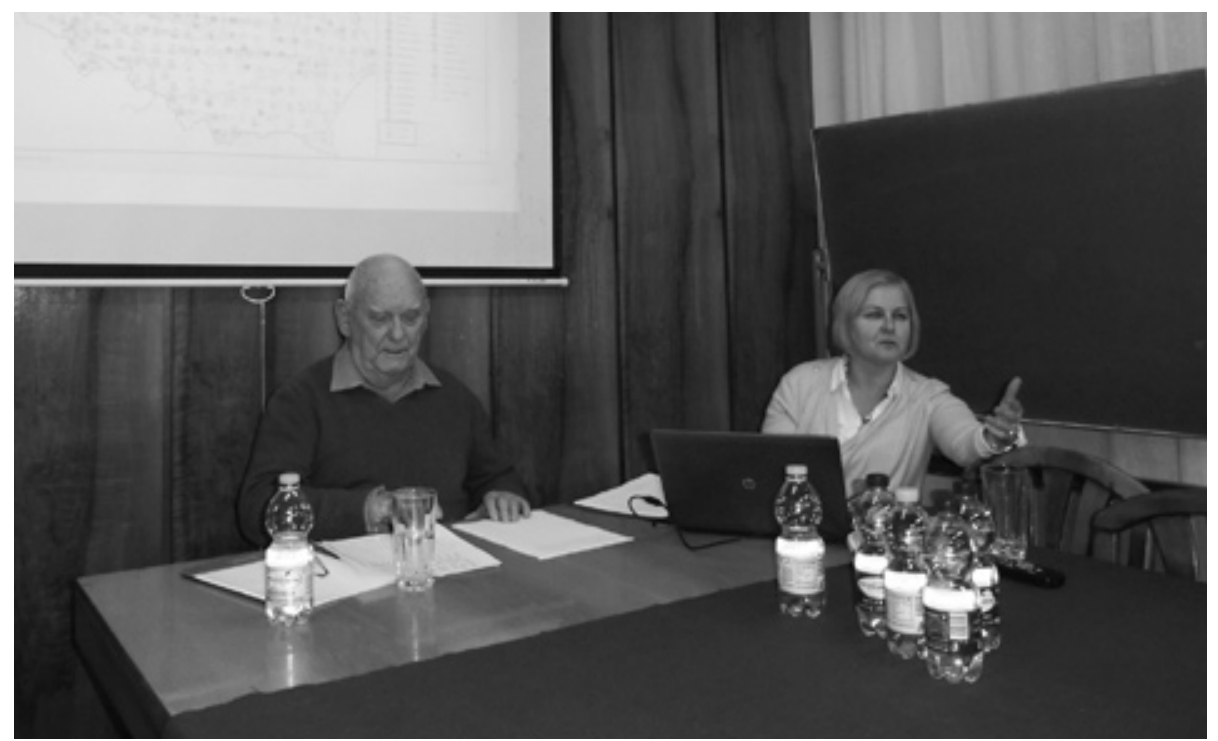

Na zdjęciu Janusz Siatkowski i Dorota K. Rembiszewska.

Spotkanie nr 3: Białystok 6 II 2019 r. 
wschodnich na terenie Polski. Powstał też problem, w jakim stopniu mamy tu do czynienia z rzeczywistymi zapożyczeniami, a kiedy trzeba przyjąć dawne nawiązania terenowe $\mathrm{w}$ wypadku różnych innowacji powstałych na pograniczu.

Po wystąpieniu referentów dyskutowano na temat leksyki gwarowej i regionalnej, charakterystycznej tylko dla północnego wschodu Polski. Obecni na spotkaniu doktoranci Wydziału Filologicznego UwB, m.in. pochodzący z Białostocczyzny, podali wiele interesujących przykładów słownictwa mającego zasięg tylko na pograniczu polsko-wschodniosłowiańskim.

Różnorodna problematyka Kolokwiów wschodnich pozwala na otwarcie się środowiska humanistycznego na różne dziedziny obszary badawcze. Poza tym spotkania są znakomitym sposobem na popularyzację wiedzy, skierowaną do nieprofesjonalistów, zainteresowanych szeroką pojętą tematyką wschodnią. 